\title{
TU/e EmonOWEN

\section{Evolution of fluorine and boron profiles during annealing in crystalline Si}

Citation for published version (APA):

López, P., Pelaz, L., Duffy, R., Meunier-Beillard, P., Roozeboom, F., Tak, van der, K., Breimer, P., Berkum, van, J. G. M., Verheijen, M. A., \& Kaiser, M. (2008). Evolution of fluorine and boron profiles during annealing in crystalline Si. Journal of Vacuum Science and Technology, B, 26(1), 377-381. https://doi.org/10.1116/1.2794738

DOI:

10.1116/1.2794738

Document status and date:

Published: 01/01/2008

\section{Document Version:}

Publisher's PDF, also known as Version of Record (includes final page, issue and volume numbers)

\section{Please check the document version of this publication:}

- A submitted manuscript is the version of the article upon submission and before peer-review. There can be important differences between the submitted version and the official published version of record. People interested in the research are advised to contact the author for the final version of the publication, or visit the $\mathrm{DOI}$ to the publisher's website.

- The final author version and the galley proof are versions of the publication after peer review.

- The final published version features the final layout of the paper including the volume, issue and page numbers.

Link to publication

\section{General rights}

Copyright and moral rights for the publications made accessible in the public portal are retained by the authors and/or other copyright owners and it is a condition of accessing publications that users recognise and abide by the legal requirements associated with these rights.

- Users may download and print one copy of any publication from the public portal for the purpose of private study or research.

- You may not further distribute the material or use it for any profit-making activity or commercial gain

- You may freely distribute the URL identifying the publication in the public portal.

If the publication is distributed under the terms of Article 25fa of the Dutch Copyright Act, indicated by the "Taverne" license above, please follow below link for the End User Agreement:

www.tue.nl/taverne

Take down policy

If you believe that this document breaches copyright please contact us at:

openaccess@tue.nl

providing details and we will investigate your claim. 


\title{
Evolution of fluorine and boron profiles during annealing in crystalline $\mathrm{Si}$
}

\author{
Pedro López ${ }^{\text {a) }}$ and Lourdes Pelaz \\ Dpto. de Electricidad y Electrónica, Universidad de Valladolid, E.T.S.I. Telecomunicación, \\ 47.011 Valladolid, Spain
}

Ray Duffy and P. Meunier-Beillard

NXP Semiconductors, Research, Kapeldreef 75, 3001 Leuven, Belgium

F. Roozeboom

NXP Semiconductors, Research, High Tech Campus 4, 5656 AE Eindhoven, The Netherlands

K. van der Tak, P. Breimer, J. G. M. van Berkum, M. A. Verheijen, and M. Kaiser

Philips Research Laboratories Eindhoven, High Tech Campus 11, 5656AE Eindhoven, The Netherlands

(Received 24 May 2007; accepted 14 September 2007; published 31 January 2008)

\begin{abstract}
In this work the authors study the interaction of $\mathrm{F}$ with point defects and the influence of $\mathrm{F}$ on $\mathrm{B}$ diffusion in crystalline $\mathrm{Si}$. The authors perform 25 and $100 \mathrm{keV} \mathrm{F}^{+}$implants and combine them with a $40 \mathrm{keV} \mathrm{Si}{ }^{+}$implant. The appearance of peaks in the $\mathrm{F}$ profile during annealing supports the idea of the formation of F complexes with vacancies and Si interstitials. In all samples implanted with $\mathrm{F}^{+}$analyzed in this work, $\mathrm{B}$ diffusion is higher than in equilibrium conditions indicating that $\mathrm{F}^{+}$ implants in crystalline Si produce a Si interstitial supersaturation. However, B diffusion is reduced when $\mathrm{F}^{+}$is coimplanted with $\mathrm{Si}$, compared to only Si implants. This effect is more evident when B is located in the region where the $\mathrm{F}^{+}$implant generates an excess of vacancies, but it also appears in the $\mathrm{Si}$ interstitial-rich region. The results indicate that the effect of $\mathrm{F}$ on B diffusion in crystalline $\mathrm{Si}$ is time dependent. () 2008 American Vacuum Society. [DOI: 10.1116/1.2794738]
\end{abstract}

\section{INTRODUCTION}

$\mathrm{F}^{+}$coimplantation with $\mathrm{B}^{+}$has been proven to have beneficial effects in the fabrication of ultrashallow junctions reducing $\mathrm{B}$ diffusion. ${ }^{1-3}$ Since $\mathrm{BF}_{2}^{+}$implants can easily amorphize the implanted Si layer and, in order to separate the role of $\mathrm{F}$ and defects, many $\mathrm{F}$ studies have been performed in preamorphized $\mathrm{Si}^{1,4,5}$ Although the formation of immobile F-B complexes was initially suggested as the cause for the reduction of B diffusion, ${ }^{6}$ more recent experimental ${ }^{1,7}$ and theoretical $^{5}$ evidence suggests that the formation of F-vacancy $(\mathrm{F}-V)$ complexes during solid-phase epitaxial regrowth is responsible for the reduction of $\mathrm{B}$ diffusion in the presence of $\mathrm{F}$ in preamorphized $\mathrm{Si}$. Those complexes would act as traps or annihilation centers for $\mathrm{Si}$ interstitials (Is) released from extended defects, reducing the $\mathrm{Si}$ interstitial supersaturation and thus B diffusion. The scenario in crystalline $\mathrm{Si}(c-\mathrm{Si})$ is much more complex since the simultaneous damage generation and $\mathrm{F}$ introduction makes it difficult to separate the role of $\mathrm{F}$ from the role of defects on $\mathrm{B}$ diffusion. $\mathrm{F}$ diffuses quite fast in $c$-Si and undergoes strong outgassing. ${ }^{8}$ The retained $\mathrm{F}$ fraction highly depends on the amount and distribution of damage and therefore on $\mathrm{F}^{+}$implant energy and dose. ${ }^{8,9}$

The mechanisms governing $\mathrm{F}$ behavior in $c$-Si and its effect on B diffusion have not been fully elucidated yet. Vuong et al. analyzed the diffusion of $\mathrm{B}$ spikes implanted with $\mathrm{Si}^{+}$, $\mathrm{F}^{+}$, and $\mathrm{Ne}^{+} .{ }^{10}$ The $\mathrm{F}^{+}$implant produced an enhancement in $\mathrm{B}$ diffusion compared to equilibrium but lower $\mathrm{B}$ diffusion than $\mathrm{Si}^{+}$and $\mathrm{Ne}^{+}$implants, though $\mathrm{Ne}$ and $\mathrm{F}$ have a similar

${ }^{\text {a) Electronic mail: pedrol@ele.uva.es }}$ atomic mass. El Mubarek et al. studied the diffusion of a B spike placed at the vacancy-rich region of the damage profile created by a high-energy $\mathrm{F}^{+}$implant. ${ }^{2}$ They observed that the reduction of $\mathrm{B}$ diffusion was correlated with the presence of vacancies $(V s)$ and the appearance of a $\mathrm{F}$ peak in the vicinity of the boron layer when high $\mathrm{F}^{+}$doses were implanted. Experiments comparing equivalent energy $\mathrm{B}^{+}$and $\mathrm{BF}_{2}^{+}$implants in $c$-Si also reveal a reduction of $\mathrm{B}$ diffusion in the presence of $\mathrm{F}^{3}$

The behavior of $\mathrm{F}$ in $c$-Si is complicated by the formation of F-defect complexes, $5,7,11,12$ which in turn may affect $\mathrm{Si}$ interstitial supersaturation and B diffusion. The aim of this work is to gain insight into the behavior of $\mathrm{F}$ in $c$-Si and to study the influence of $\mathrm{F}$ on $\mathrm{B}$ diffusion.

\section{EXPERIMENTAL PROCEDURE}

Two B-doped layers were grown by chemical vapor deposition at depths of 120 and $440 \mathrm{~nm}$ to act as diffusion markers. B peak concentration is low, approximately 2.5 $\times 10^{18} \mathrm{~cm}^{-3}$, to minimize the formation of boron interstitial clusters (BICs). A F ${ }^{+}$dose of $5 \times 10^{14} \mathrm{~cm}^{-2}$ was implanted at energies of 25 or $100 \mathrm{keV}$ to introduce a large $\mathrm{F}$ dose into the sample without causing amorphization. A $40 \mathrm{keV} 5$ $\times 10^{13} \mathrm{~cm}^{-2} \mathrm{Si}^{+}$implant, whose mean projected range $\left(R_{p}\right)$ is similar to that of the $25 \mathrm{keV} \mathrm{F}^{+}$implant, alone or combined with one of the two described $\mathrm{F}^{+}$implants, was also done. The combination of the $\mathrm{Si}^{+}$and $\mathrm{F}^{+}$implants allows us to study the effect of $\mathrm{F}$ with preexisting damage. A sample with no implants was used as a reference for equilibrium B diffusion. All samples were annealed at $850{ }^{\circ} \mathrm{C}$ for 18,180 , or 1800 s. Secondary ion mass spectrometry (SIMS) was 


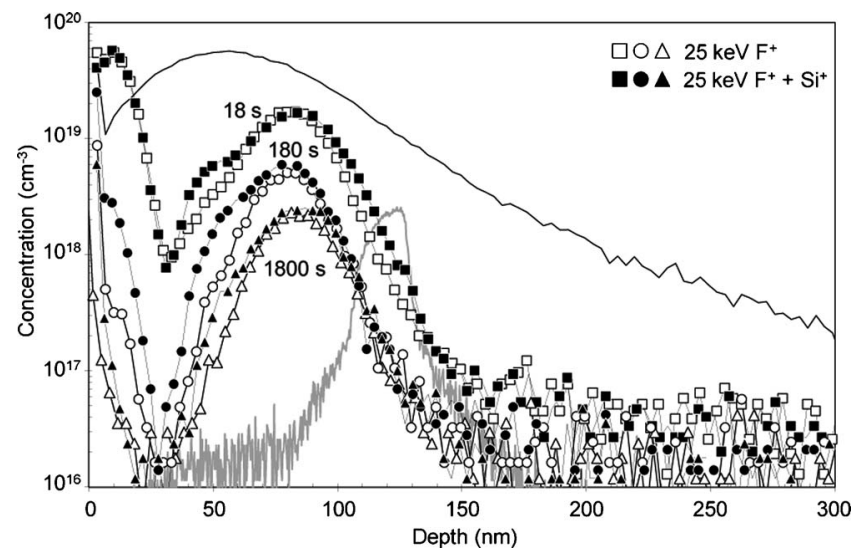

FIG. 1. F SIMS profiles for $5 \times 10^{14} \mathrm{~cm}^{-2} 25 \mathrm{keV} \mathrm{F} \mathrm{F}^{+}$implant (open symbols) alone or coimplanted with $5 \times 10^{13} \mathrm{~cm}^{-2} 40 \mathrm{keV} \mathrm{Si}^{+}$(solid symbols) during annealing at $850{ }^{\circ} \mathrm{C}$ for 18,180 , or $1800 \mathrm{~s}$. The as-implanted $\mathrm{F}^{+}$ profile and the as-grown shallow B spike are also plotted. The deeper part of the implanted region, including the deep B spike, is not shown for clarity.

used to analyze $\mathrm{B}$ and $\mathrm{F}$ profiles and transmission electron microscopy (TEM) to detect the presence of extended defects.

\section{RESULTS}

\section{A. Low-energy fluorine implant}

The evolution of $\mathrm{F}$ profiles during annealing at $850{ }^{\circ} \mathrm{C}$ for the $25 \mathrm{keV} \mathrm{F}^{+}$implant with or without the $\mathrm{Si}^{+}$coimplant is plotted in Fig. 1. Two peaks are observed in the profiles, one slightly deeper than $R_{p}$, centered at $\sim 80 \mathrm{~nm}$, and another one in the proximity of the surface. As the annealing proceeds the retained $\mathrm{F}$ dose decreases, as reported in Table I. In the sample implanted only with $\mathrm{F}^{+}, 24 \%$ of the implanted dose remains after $18 \mathrm{~s}$ annealing and only $4 \%$ is retained after $180 \mathrm{~s}$. When $\mathrm{Si}^{+}$and $\mathrm{F}^{+}$are coimplanted, the amount of retained F is similar but a "shoulder" on F profile around $R_{p}$ is observed. Plan-view TEM images of both samples after annealing at $850{ }^{\circ} \mathrm{C}$ for $18 \mathrm{~s}$, shown in Fig. 2, reveal a rather large density of 311 defects and dislocation loops, on the order of $10^{10}$ defects $/ \mathrm{cm}^{2}$. In the case of $\mathrm{F}^{+}$ coimplantation with $\mathrm{Si}$ a slightly higher density of defects is observed.

The presence of these defects causes B diffusion enhancement. Figure 3 shows B profiles during annealing at $850{ }^{\circ} \mathrm{C}$ for 18 or $180 \mathrm{~s}$ in the samples implanted with 5 $\times 10^{14} \mathrm{~cm}^{-2} 25 \mathrm{keV} \mathrm{F}+5 \times 10^{13} \mathrm{~cm}^{-2} 40 \mathrm{keV} \mathrm{Si}^{+}$, and

TABLE I. F retained dose fraction (\%) during annealing at $850{ }^{\circ} \mathrm{C}$ for the samples implanted with $5 \times 10^{14} \mathrm{~cm}^{-2} 25$ or $100 \mathrm{keV} \mathrm{F}^{+}$and the same $\mathrm{F}^{+}$ implant plus $5 \times 10^{13} \mathrm{~cm}^{-2} 40 \mathrm{keV} \mathrm{Si}$.

\begin{tabular}{lccc}
\hline \hline \multicolumn{1}{c}{ Sample/anneal time } & $18 \mathrm{~s}$ & $180 \mathrm{~s}$ & $1800 \mathrm{~s}$ \\
\hline $25 \mathrm{keV} \mathrm{F}^{+}$ & 24 & 4 & 2 \\
$25 \mathrm{keV} \mathrm{F}^{+}+40 \mathrm{keV} \mathrm{Si}^{+}$ & 27 & 5 & 2 \\
$100 \mathrm{keV} \mathrm{F}^{+}$ & 49 & 23 & 16 \\
$100 \mathrm{keV} \mathrm{F}^{+}+40 \mathrm{keV} \mathrm{Si}^{+}$ & 39 & 20 & 16 \\
\hline \hline
\end{tabular}
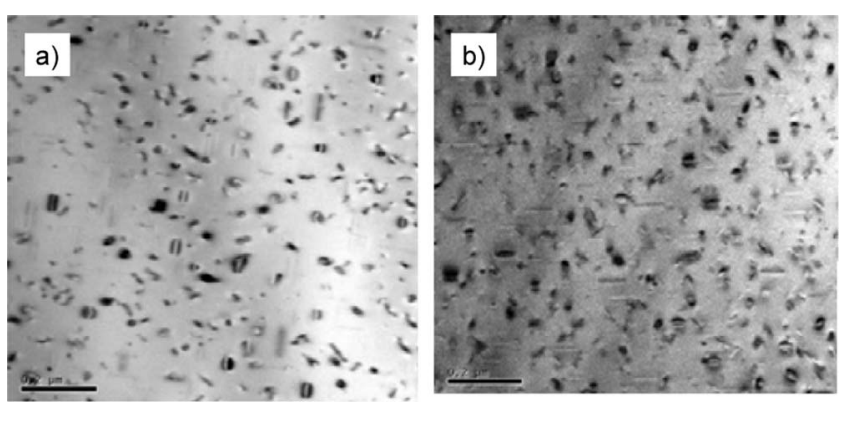

FIG. 2. Plan-view TEM images after annealing at $850{ }^{\circ} \mathrm{C}$ for $18 \mathrm{~s}$ for (a) 25 $\mathrm{keV} 5 \times 10^{14} \mathrm{~cm}^{-2} \mathrm{~F}^{+}$implant; (b) same $\mathrm{F}^{+}$implant plus $40 \mathrm{keV} 5$ $\times 10^{13} \mathrm{~cm}^{-2} \mathrm{Si}^{+}$.

coimplanted with $\mathrm{Si}^{+}$and $\mathrm{F}^{+}$. In all implanted samples $\mathrm{B}$ diffusion is higher than in equilibrium conditions. After $18 \mathrm{~s}$ the samples enriched with $\mathrm{F}^{+}$present lower $\mathrm{B}$ diffusion than that in the sample only implanted with $\mathrm{Si}^{+}$. This reduction in $\mathrm{B}$ diffusion is observed in both spikes, though it is more evident in the shallow one. In this spike the time-averaged B diffusivity after $18 \mathrm{~s}$ is reduced by a factor of $\sim 0.6$ in samples implanted with $\mathrm{F}^{+}$or $\mathrm{F}^{+}$and $\mathrm{Si}^{+}$, compared to the sample only implanted with $\mathrm{Si}^{+}$. Note that only the shallow $\mathrm{B}$ spike is directly covered by $\mathrm{F}$, as shown in Fig. 1. After 180 $\mathrm{s}$ B profiles are similar in all implanted samples.

\section{B. High-energy fluorine implant}

The $\mathrm{F}$ profiles during annealing at $850{ }^{\circ} \mathrm{C}$ for the 100 $\mathrm{keV} \mathrm{F}^{+}$implant are plotted in Fig. 4. The figure includes the

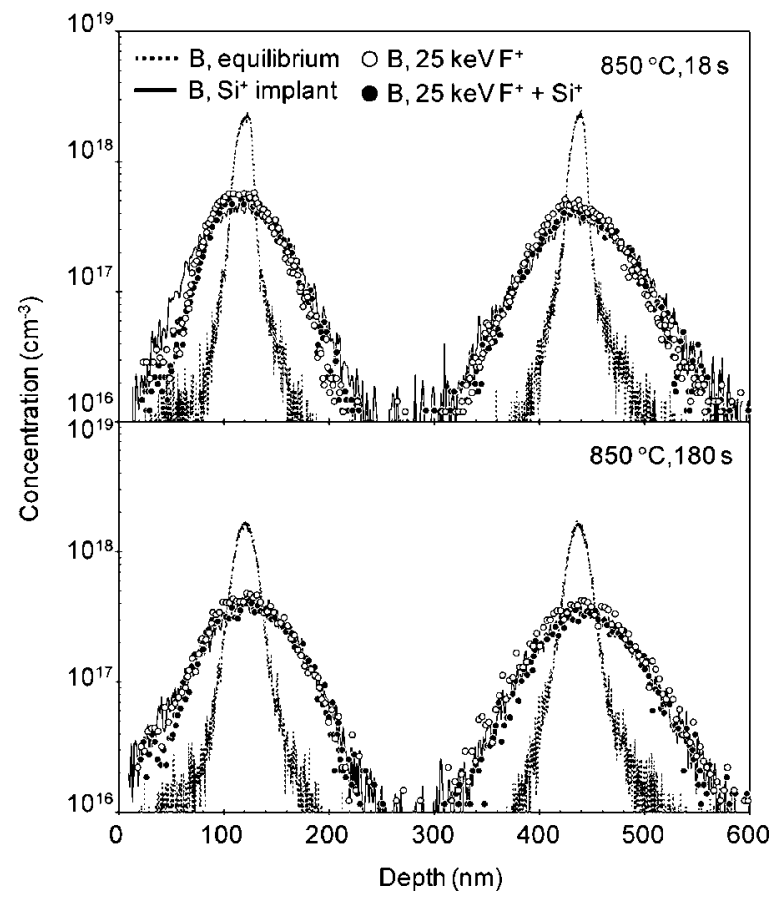

FIG. 3. B SIMS profiles during annealing at $850{ }^{\circ} \mathrm{C}$ for 18 or $180 \mathrm{~s}$ for the samples implanted with $5 \times 10^{14} \mathrm{~cm}^{-2} 25 \mathrm{keV} \mathrm{F}^{+}$(open symbols), 5 $\times 10^{13} \mathrm{~cm}^{-2} 40 \mathrm{keV} \mathrm{Si}^{+}$(solid line), and coimplanted with $\mathrm{F}^{+}$and $\mathrm{Si}^{+}$(solid symbols). B spikes in equilibrium conditions (no implants) are also shown (dotted lines). 


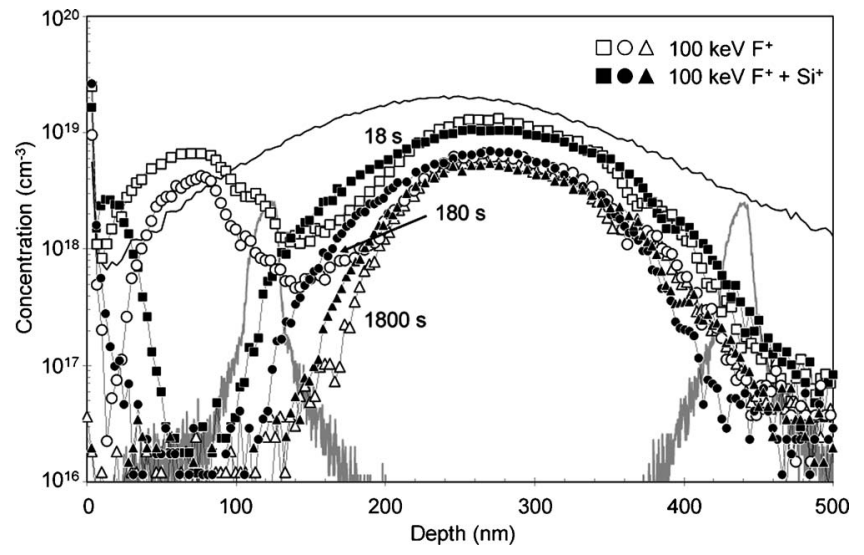

FIG. 4. F SIMS profiles for $5 \times 10^{14} \mathrm{~cm}^{-2} 100 \mathrm{keV} \mathrm{F}$ (open symbols) and the same $\mathrm{F}^{+}$implant plus $5 \times 10^{13} \mathrm{~cm}^{-2} 40 \mathrm{keV} \mathrm{Si}^{+}$(solid symbols) during annealing at $850{ }^{\circ} \mathrm{C}$ for 18,180 , or $1800 \mathrm{~s}$. The as-implanted $\mathrm{F}$ profile and the as-grown $\mathrm{B}$ spikes are also included.

distribution when only $\mathrm{F}^{+}$is implanted and the coimplantation of $\mathrm{F}^{+}$and $\mathrm{Si}^{+}$. The two-peak $\mathrm{F}$ distribution observed for the low $\mathrm{F}^{+}$implant energy is more prominent for higher $\mathrm{F}^{+}$ implant energy. The shallower implant peak is located around $\sim 60 \mathrm{~nm}$ and survives annealing for $180 \mathrm{~s}$, but it disappears after $1800 \mathrm{~s}$. Note that for the shortest monitored time the F concentration at the shallow peak exceeds that of the as-implanted profile. In the sample coimplanted with $\mathrm{F}^{+}$ and $\mathrm{Si}^{+}$there is a $\mathrm{F}$ depletion at the position of the shallow $\mathrm{F}$ peak reported when only $\mathrm{F}^{+}$was implanted, but some $\mathrm{F}$ accumulation is observed closer to the surface. The deeper $\mathrm{F}$ peak survives longer and it is slightly wider when $\mathrm{Si}^{+}$is coimplanted. As shown in Table I, the retained F dose is higher than for the $25 \mathrm{keV}$ implants. $\mathrm{Si}^{+}$coimplantation reduces the total retained $\mathrm{F}$ dose mostly because of the strong reduction of $\mathrm{F}$ in the shallow peak. Cross-section TEM images shown in Fig. 5 reveal the existence of a band of defects around $R_{p}$ of the $\mathrm{F}^{+}$implant. This band is slightly wider in the sample coimplanted with $\mathrm{Si}^{+}$as seen in Fig. 5(b). No defects are visible close to the surface.

Figure 6 reports the B SIMS profiles after annealing at $850{ }^{\circ} \mathrm{C}$ for 18 or $180 \mathrm{~s}$ in the samples implanted with 5 $\times 10^{14} \mathrm{~cm}^{-2} 100 \mathrm{keV} \mathrm{F}^{+}, 5 \times 10^{13} \mathrm{~cm}^{-2} 40 \mathrm{keV} \mathrm{Si}^{+}$, and coimplanted with $\mathrm{F}^{+}$and $\mathrm{Si}^{+}$. It is clearly shown that $\mathrm{B}$ dif-

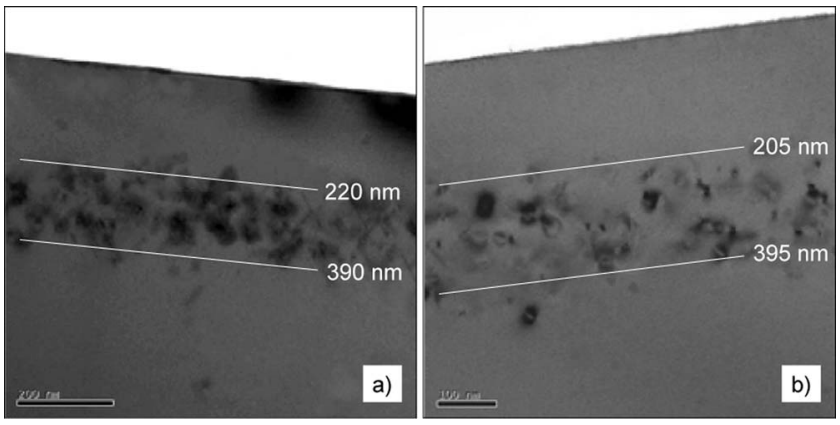

FIG. 5. Cross section TEM images after annealing at $850{ }^{\circ} \mathrm{C}$ for $18 \mathrm{~s}$ for (a) $5 \times 10^{14} \mathrm{~cm}^{-2} 100 \mathrm{keV} \mathrm{F}^{+}$; (b) same F $\mathrm{F}^{+}$implant plus $5 \times 10^{13} \mathrm{~cm}^{-2} 40 \mathrm{keV}$ $\mathrm{Si}^{+}$.

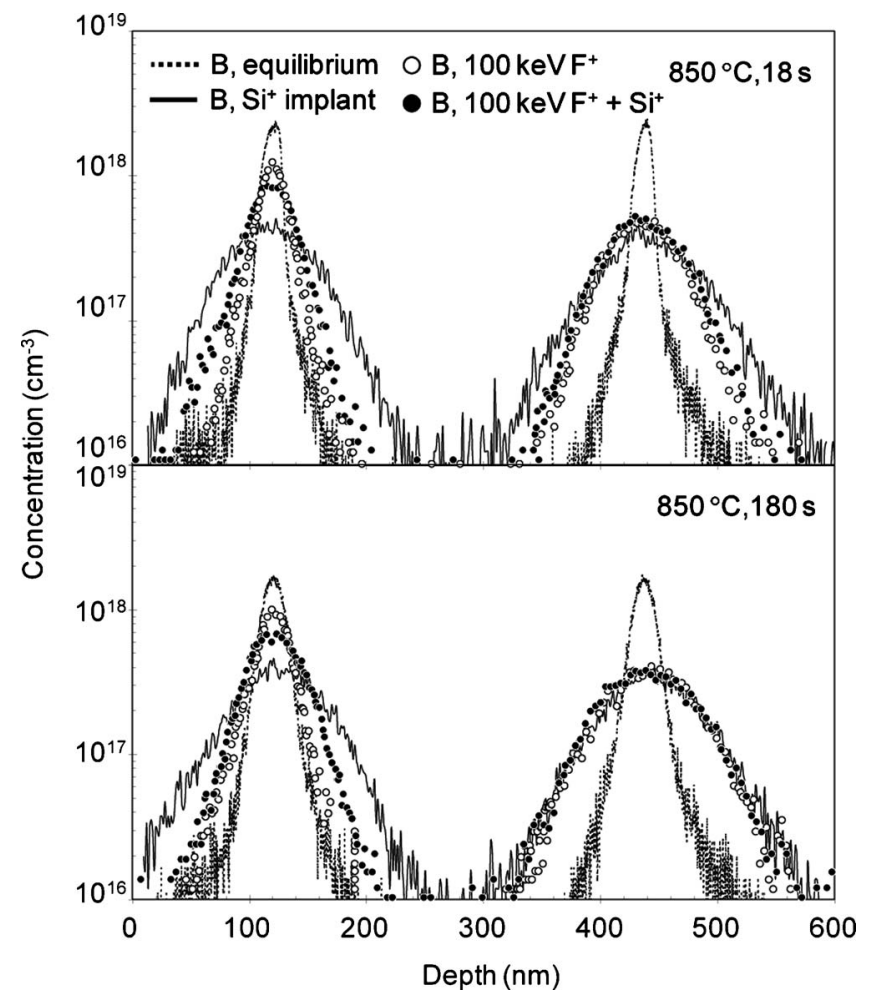

FIG. 6. B SIMS profiles after annealing at $850{ }^{\circ} \mathrm{C}$ for 18 or $180 \mathrm{~s}$ in the samples implanted with $5 \times 10^{14} \mathrm{~cm}^{-2} 100 \mathrm{keV} \mathrm{F}^{+}$(open symbols), 5 $\times 10^{13} \mathrm{~cm}^{-2} 40 \mathrm{keV} \mathrm{Si}^{+}$(solid line), and coimplanted with $\mathrm{F}^{+}$and $\mathrm{Si}^{+}$(solid symbols). B spikes in equilibrium conditions (no implants) are also included (dotted lines).

fusion in samples enriched with $\mathrm{F}$ is lower than that produced by the $\mathrm{Si}^{+}$implant. This is especially remarkable in the shallow spike, in which the time-averaged B diffusivity after $18 \mathrm{~s}$ is reduced by approximately 0.04 and 0.2 when $\mathrm{F}^{+}$or $\mathrm{F}^{+}$ and $\mathrm{Si}^{+}$are implanted, respectively, compared to the $\mathrm{Si}^{+}$implant. As the anneals proceed the reduction on B diffusion is still visible in the shallow spike, but the deeper spike presents similar diffusion for all implanted samples.

\section{DISCUSSION}

The analysis of the implanted $\mathrm{F}$ profile evolution during annealing reveals that $\mathrm{F}$ atoms are highly mobile and they evaporate when they reach the surface. For $\mathrm{F}^{+}$implant doses lower than those used in this work, $\mathrm{F}$ completely outgases at temperatures as low as $750{ }^{\circ} \mathrm{C}$. In our case, a fraction of $\mathrm{F}$ implanted dose is retained around two well-defined peaks, one near the surface and the other one around $R_{p}$. The gettering of impurities in these zones has been reported before ${ }^{13}$ and it has been associated with regions with excess $V \mathrm{~s}$ and $\mathrm{Si}$ Is, respectively. Due to the momentum transfer of the incoming ion, there is a net spatial separation of point defects in the generated cascade: empty lattice sites $(V \mathrm{~s})$ are predominant close to the surface while excess Si Is are placed slightly deeper than $R_{p}$. Thus, $\mathrm{F}$ depth distribution with two marked peaks observed in Figs. 1 and 4 correlates with the presence of vacancy and Si interstitial defects in these regions. Crosssection TEM images of the high-energy F samples (Fig. 5) 
show the presence of a band of $\mathrm{Si}$ interstitial type defects (311s and dislocation loops) located around $R_{p}$, just in the region where most $\mathrm{F}^{+}$ions remain associated with the deep $\mathrm{F}$ peak. This fact suggests that the deep F peak may correspond to the formation of F-interstitial (F-I) complexes. The existence of these kinds of complexes has been previously proposed in the literature. ${ }^{11,12}$ No defects are observed in the shallow region in TEM images, probably because they are too small to be detected by TEM. However, the fact that the shallow F peak observed in the sample only implanted with $\mathrm{F}^{+}$disappears when $\mathrm{Si}^{+}$is coimplanted in that region suggests the presence of vacancy-type defects. The $\mathrm{Si}^{+}$implant adds extra $\mathrm{Si} I \mathrm{~s}$ that annihilate the excess $V \mathrm{~s}$ created by the high-energy $\mathrm{F}^{+}$implant in the shallow region. By performing an oxidizing annealing (which is known to set a Si interstitial supersaturation at the surface), Kham et al. also observed the suppression of the shallow F peak. ${ }^{14}$ These observations support the idea that the two peak $\mathrm{F}$ distribution can be associated with the interaction of $\mathrm{F}$ with $V \mathrm{~s}$ and $\mathrm{Si} I \mathrm{~s}$, respectively.

The formation of F- $V$ and F- $I$ complexes prevents $\mathrm{F}$ from outgassing. The retained $\mathrm{F}$ dose is related to the amount and distribution of defects. In the $25 \mathrm{keV} \mathrm{F}^{+}$implant, the coimplantation of $\mathrm{Si}^{+}$with similar $R_{p}$ adds more damage that overlaps with that produced by $\mathrm{F}^{+}$ions but the retained $\mathrm{F}$ dose is practically the same. In these conditions a "shoulder" is observed on the $\mathrm{F}$ profile around $R_{p}$ that may represent F-rich F-I complexes formed due to the extra damage generated by the $\mathrm{Si}^{+}$implant. Kham et al. observed a similar shoulder, attributed to F- $V$ complexes, but in their work it was located between 0.5 and $0.7 R_{p}{ }^{14}$ In the $100 \mathrm{keV} \mathrm{F}^{+}$ implant, $\mathrm{F}^{+}$ions penetrate much deeper and more damage is generated in the lattice. Since defects are farther from the surface, $\mathrm{F}$ atoms are more likely to interact with them before they evaporate when reaching the surface. Therefore, the amount of retained $\mathrm{F}$ in the $100 \mathrm{keV}$ implant is higher than that in the lower energy $\mathrm{F}^{+}$implant. In this case, the $\mathrm{Si}^{+}$ coimplantation is responsible for the annihilation of $V \mathrm{~s}$ in the shallower region, which prevents the trapping of $\mathrm{F}$ in that region reducing the retained $\mathrm{F}$ dose.

$\mathrm{B}$ redistribution is strongly affected by the presence of damage since B-enhanced diffusion is directly related to the Is supersaturation. Ab initio calculations indicate that $\mathrm{F}$ tends to remain interstitial rather than to occupy a substitutional position. ${ }^{15}$ Thus, no excess Si interstitial is generated by the implanted ion as it occurs with other ions when they become substitutional. This fact may explain the reduced B diffusion observed in $\mathrm{F}^{+}$implants, when compared with $\mathrm{Si}^{+}$or $\mathrm{Ne}^{+} .10$ Nevertheless, the momentum transfer of the incoming energetic ion produces some net separation between $\mathrm{Si} I$ s and the corresponding $V \mathrm{~s}$ which leads to local excess of $V \mathrm{~s}$ closer to the surface and Si Is deeper. This separation favors an incomplete $I-V$ recombination and allows the formation of vacancy and $\mathrm{Si}$ interstitial complexes. In fact, TEM images reveal the presence of a large amount of 311s and dislocation loop defects for all $\mathrm{F}^{+}$implants analyzed in this work. As a result a $\mathrm{Si} I$ s supersaturation is established and a B diffusion significantly higher than the equilibrium value is observed in all samples considered in this study.

When $\mathrm{F}^{+}$is implanted at high energies, the vacancy-rich region (associated with the shallow $F$ peak) overlaps the $B$ spike closer to the surface. As a result, B diffusion in this spike is much lower in the samples enriched with $F$ than when only $\mathrm{Si}^{+}$is implanted, as plotted in Fig. 6. In fact, among all samples, the shallow B spike in the sample implanted with $5 \times 10^{14} \mathrm{~cm}^{-2} 100 \mathrm{keV} \mathrm{F} \mathrm{F}^{+}$underwent the lowest diffusion. The reduced $\mathrm{B}$ diffusion observed is probably due to the presence of an excess of $V \mathrm{~s}$ which annihilate the $\mathrm{Si}$ Is that could be injected from the Si interstitial-rich region. This result is consistent with experimental observations by El Mubarek et al. ${ }^{2}$ The coimplantation with $\mathrm{Si}^{+}$adds extra damage in the region of the shallow spike which reduces the amount of $V$ s and increases $B$ diffusion.

However, a reduction in B diffusion is also observed even in the Si interstitial-rich region. Although $\mathrm{F}$ adds some damage, the coimplantation of $\mathrm{F}^{+}$and $\mathrm{Si}^{+}$reduces $\mathrm{B}$ diffusion when compared with only the $\mathrm{Si}^{+}$implant, as shown in Figs. 3 and 6 for the $18 \mathrm{~s}$ anneal. For the $25 \mathrm{keV} \mathrm{F}^{+}$implant the reduction on $\mathrm{B}$ diffusion is observed in both spikes, though it is larger in the shallow one, the only one which is directly covered by the implant damage and by $\mathrm{F}$. In the sample implanted with $100 \mathrm{keV} \mathrm{F}^{+}$the deep B spike, located in the $\mathrm{Si}$ interstitial-rich region, also undergoes a reduced diffusion. Although a chemical F-B interaction cannot be completely ruled out from this experiment, the formation of stable defects in the samples enriched with $\mathrm{F}$ that reduce the Si interstitial supersaturation could explain the reduction of B diffusion by $\mathrm{F}^{+}$implants. Defects generated by the $\mathrm{Si}^{+}$implant are probably small clusters and 311 defects that set a high Is supersaturation and dissolve quickly, since no defects were observed in TEM images after 18 s. However, in samples enriched with $\mathrm{F}$, stable defects such as dislocation loops form. They set a low interstitial supersaturation and remain longer. Note also that, though B concentration is low, BICs may have been formed in those spikes surrounded by implant damage. This may reduce the amount of mobile B atoms available for diffusion which can also play a role in the reported B diffusion reduction. After $180 \mathrm{~s}$ B profiles in $\mathrm{Si}$ interstitial-rich regions are similar with or without the $\mathrm{F}^{+}$ implant, which indicates that the effect of $\mathrm{F}$ on $\mathrm{B}$ diffusion seems to be time dependent.

\section{CONCLUSIONS}

F retention observed in SIMS profiles can be associated with the formation of F- $V$ complexes in the $V$-rich region close to the surface and F-interstitial complexes in the highly damaged region around $R_{p} .5 \times 10^{14} \mathrm{~cm}^{-2} \mathrm{~F}^{+}$implants produce a large density of $311 \mathrm{~s}$ and dislocation loops, which cause B diffusion enhancement. However, B diffusion is reduced when $\mathrm{F}^{+}$is coimplanted with $\mathrm{Si}^{+}$, compared to only $\mathrm{Si}^{+}$implants. This effect is more evident when $\mathrm{B}$ is located in the region where $\mathrm{F}^{+}$implant generates an excess of $V \mathrm{~s}$, but it also appears in the Si interstitial-rich region. The F effect on B diffusion in $c$-Si seems to be time dependent, and may be 
related to the formation of stable defects in the samples enriched with $\mathrm{F}$ that reduce the Si interstitial supersaturation.

\section{ACKNOWLEDGMENTS}

This work has been funded by the Spanish DGI under Project TEC2005-05101 and the JCyL Consejería de Educación y Cultura under Project VA070A05.

${ }^{1}$ G. Impellizzeri, S. Mirabella, F. Priolo, E. Napolitani, and A. Carnera, J. Appl. Phys. 99, 103510 (2006).

${ }^{2}$ H. A. W. El Mubarek, J. M. Bonar, G. D. Dilliway, P. Ashburn, M. Karunaratne, A. F. Willoughby, Y. Wang, P. L. F. Hemment, R. Price, J. Zhang, and P. Ward, J. Appl. Phys. 96, 4114 (2004).

${ }^{3}$ J. Park, Y.-J. Huh, and H. Hwang, Appl. Phys. Lett. 74, 1248 (1999).

${ }^{4}$ S. Paul, W. Lerch, B. Colombeau, N. E. B. Cowern, F. Cristiano, S. Boninelli, and D. Bolze, J. Vac. Sci. Technol. B 24, 437 (2006).

${ }^{5}$ G. M. Lopez, V. Fiorentini, G. Impellizzeri, S. Mirabella, and E. Napolitani, Phys. Rev. B 72, 045219 (2005).

${ }^{6}$ A. Mokhberi, R. Kasnavi, P. B. Griffin, and J. D. Plummer, Appl. Phys.
Lett. 80, 3530 (2002).

${ }^{7}$ D. A. Abdulmalik, P. G. Coleman, N. E. B. Cowern, A. J. Smith, B. J. Sealy, W. Lerch, S. Paul, and F. Cristiano, Appl. Phys. Lett. 89, 052114 (2006).

${ }^{8}$ R. R. Robison and M. E. Law, in International Electron Device Meeting (IEDM) Technical Digest (2002), Vol. 883.

${ }^{9}$ D. F. Downey and K. S. Jones, in Ion Implantation Technology Conference, IEEE Vol. 897 (1999).

${ }^{10}$ H.-H. Vuong, H.-J. Gossman, C. S. Rafferty, H. S. Luftman, F. C. Unterwald, D. C. Jacobson, R. E. Ahrens, T. Boone, and P. M. Zeitzoff, J. Appl. Phys. 77, 3056 (1995).

${ }^{11}$ R. R. Robison, A. F. Saavedra, and M. E. Law, Mater. Res. Soc. Symp. Proc. 810, 363 (2004).

${ }^{12}$ H. A. W. El Mubarek and P. Ashburn, Appl. Phys. Lett. 83, 4134 (2003).

${ }^{13}$ V. C. Venezia, D. J. Eaglesham, T. E. Haynes, A. Agarwal, D. C. Jacobson, H.-J. Gossmann, and F. H. Baumann, Appl. Phys. Lett. 73, 2980 (1998).

${ }^{14}$ M. N. Kham, H. A. W. El Mubarek, J. M. Bonar, and P. Ashburn, Appl. Phys. Lett. 87, 011902 (2005).

${ }^{15}$ M. Diebel and S. T. Dunham, Mater. Res. Soc. Symp. Proc. 717, C4.5.1 (2002). 